\title{
THE IMPACT OF THE ARAB SPRING ON HOTEL SERVICES IN ISTANBUL
}

\author{
Mehmet Emin Baynazoglu, Ass. Prof. Dr. ${ }^{1}$ \\ Ebru Ozlem Bilgin, Ass. Prof. Dr. ${ }^{2}$ \\ Orhan Akova, Prof. Dr. ${ }^{3}$
}

DOI: https://doi.org/10.31410/tmt.2018.63

\begin{abstract}
The tourism industry is affected by many different external factors such as war, terrorism and economic crisis and it plays an important role in many aspects for the development of a country. One of the major political events occurred in Arab countries in recent years was Arab Spring. In this study, changes occurring in tourist profiles' expectations in hospitality services in Istanbul hotels with the Arab Spring and were studied to reveal changes in the profile of tourists visiting İstanbul. Face to face interview method was used for this qualitative study with 8 senior managers who work in 5-star hotels in Istanbul. The responses obtained were subjected to content analysis and tourism practitioners' perceptions and experiences were applied to them. In the direction of the findings from the interviews, it is observed that there are significant changes in the tourist profiles in the 5-star hotel enterprises operating in Istanbul after the Arab Spring which occurred in 2010. This change seems to have caused the hotels to revise themselves on many issues such as human resources, education, food and beverage, cost control, renovation, and refurbishment.
\end{abstract}

Keywords: Arab Spring, Tourism, Tourist Profiles, Service Features.

\section{INTRODUCTION}

$\mathrm{P}$ eople who spend more than 24 hours in the country, visit and stay in a facility while carrying out the activities for their personal purposes are called tourists [1]. The concept of the profile is defined as "the whole of distinctive features for a person or an item". The determination of the tourist profile benefits and guides planning, management, and marketing in tourism. The knowledge of tourist profile allows administrators to address different motivations and experiences and enables them to determine which tourist profile is included in which type of tourism. Meanwhile, the determination of the tourist profile ensures the correct and efficient uses of resources in terms of sustainable tourism [2]. The concept of tourist profile consists of four elements; demographic, geographical, psychological, and socio-economic characteristics. The factors that make up the demographic profile are age, gender, marital status, occupation, nationality, and the number of participants in the trip. Demographic variables are one of the important issues to consider when analyzing the satisfaction from a touristic spot. Demographic variables are widely used to determine tourist profile in tourism researches. The geographical profile concerns the country or city where the tourist arrives. The factors that make up the psychological profile are the tourist's purpose of the visit, leisure activities, length of stay, and accommodation preferences. Lastly, the factors that make up the socio-economic profile are annual income, level of education, type of transportation, amount of expenditure, and price flexibility [3] - [4] - [5]. Tourism sector began to be promoted in the 1980s in Turkey. "Mass tourism" is among the first types of tourism that are encouraged. Therefore, the leading cause

1 Trakya University, Kesan Yusuf CAPRAZ School of Applied Sciences, Turkey

2 Sakarya University, Tourism Faculty, Sapanca Campus, Turkey

3 Istanbul University, Faculty of Economics, Beyazit, Istanbul, Turkey 
of foreign tourists prefer Turkey is seen as the sea-sand-sun tourism. However, in the post-2000 period, significant increases in the number of tourists coming to Turkey for conference, meeting, business purposes are observed apart from the mass tourism.

A competition among the tourism destinations also exists just like other industries. Studies are carried out that give priority to the expectations and needs of tourists. It is necessary to identify the factors that motivate them to purchase the products and services to understand which destinations consumers choose and why. In this context, to estimate and understand the demand for tourism destination, it is necessary to observe and determine the consumer behaviors. One of the methods of determining consumer behavior is revealing the consumer profile. In other words, it is to determine the detailed information of tourists visiting the region. In this study, the changes in the tourist profile coming to Turkey due to the Arab Spring and the expectations of this tourist profile were focused [6], [7].

\section{THE ARAB SPRING}

The term of Arab Spring is being used to name the popular movements on different scales that have recently taken place in the Middle East against oppressive and authoritarian governments and to express this very process as a wave of democratization [8]. In this context, the protests and demonstrations are also known as Arab Spring and Winter, Arab Awakening, Arab Rebellion, Arab Uprisings, and Arab Revolution in the social media as well as researches related to the subject. People's movements first started with the burning of Mohammed Bouzazi in Tunisia. The popular movements that began on December 18, 2010, resulted in revolutions in Tunisia and Egypt. In Libya, it resulted in a civil war that toppled the Gaddafi regime in 2011 autumn. There have been small protests in Kuwait, Lebanon, Mauritania, Saudi Arabia, Sudan, and Western Sahara, large protests in Israel, Algeria, Iraq, Jordan, Morocco, and Oman, and big riots in Bahrain, Syria, and Yemen. The conflicts in Israeli border in May 2011 were observed to be inspired by the Arab Spring. Many problems such as unemployment, food insufficiency, inflation, political corruption, lack of freedom of expression, irregularities and bad living conditions in the Arab world triggered the spread of these movements and protests by showing domino effect in the mentioned countries [9]. In general, it is seen that the basic determining power in the Middle East is the military. In Egypt and Libya, the army left Husnu Mubarak and Muammar Gaddafi alone, yet in Syria, the army took sides with Assad to suppress the rebellion. It should be stated that although the conditions are different from each other, it is seen that the Middle East countries have experienced this transformation at the same time [10]. As they have similar cultural, economic, and political structures, the reactions of the Gulf states to the Arab Spring are parallel to each other. The main factors determining the traditional foreign policy understandings of these countries have also determined the attitudes towards the Arab Spring. The general policy of the Gulf countries in the face of the Arab revolts has been that making some reforms to calm the people and preserving the power rather than the regime change. For this purpose, several economic, political, and social reforms have been carried out and more are promised, and different policies have been followed from one country to another. United Arab Emirates (UAE) and Qatar have become the two exceptional Arab states that benefited from Arab rebellions in addition not to experience similar internal conflicts, while the Gulf monarchs are affected by the increasingly effective rebellions in the region [11].

Tunisia is the country where the Arab Spring uprisings began in December 2010, then triggered a wave of political confusion along North Africa and the Middle East [12]. Then the kingdom of Saudi Arabia banned the demonstrations by Shiites, the minority group of the country, fol- 
lowing the fall of regimes in Tunisia and Egypt. In addition, the Saudi Arabian government announced an economic package worth 130 billion USD to prevent a possible outbreak of the uprising in the country at the beginning of the rebellions. Saudi Arabia has put these economic aid and reform policies into practice to reduce the demands for regime change as well as to decrease the internal pressures [13]. The wave of Arab revolt has also visited Kuwait, which is regarded as the most "democratic" country of the Gulf region, and it left its impact when it coincided with the allegations of corruption in the country.

Kuwait Emiri interpreted the invading of the parliament as a threat to the security and stability of the country and instructed to take strict security measures against the demonstrations during the anti-corruption protests in the country. Oman, which has a relatively closed social structure, hence seen as a country that would be the least affected due to regional events, has also experienced the wave of uprisings. Unlike the countries of the region, Oman has been able to suppress the popular uprisings in the country peacefully [13].

The problems of political stability experienced by negative events, both human and natural, are influential in the preference of tourists for a region. Some countries periodically announce to their citizens the countries they should not travel to. In these announcements, the kinds of crime or violence occurring in those places planned to go are also stated. Destinations in which crime and violence occur and where political instability exists have negative perceptions in tourists' minds. During the Arab Spring, it was wondered how the Arab countries, that are the tourist attraction centers, are influenced by this process involving political instability. This study has attempted to reveal what are the changes in the tourist profile coming to Turkey after the Arab Spring.

\section{RESEARCH METHODOLOGY}

\subsection{Research Method and Aim}

In this study, which is a qualitative research, data were obtained by making face to face interviews with 8 senior executives in 5-star hotels in Istanbul. The responses obtained were subjected to content analysis and tourism practitioners' perceptions, and experiences were evaluated.

It is an important research topic to find out how the influence of political factors, which are considered as macro (external) factors, affect enterprises on business activities and how to develop appropriate strategies and tactics for these effects. The purpose of this study is to determine the changes that the Arab Spring brought about in the services of the hotels in Istanbul and the changes that occurred in the tourist profiles coming to Istanbul, and the structure of their expectations.

\subsection{Data Obtaining Method and Tools}

Five open-ended questions were directed to 8 senior managers of five 5-star hotel enterprises located in the Beşiktaş district of Istanbul and interviews were conducted face-to-face. These 8 executives are 5 General Managers, 1 Sales Manager, 1 Marketing Manager, and 1 Business Development Manager. Each manager interviewed was given a number from 1 to 8 , and the responses were compiled using this numbering method. Responses from the executives were recorded on the mobile phone as a voice recording with their permission obtained while the researchers took notes of the answers with handwriting. The conversation did not turn into a 
dialogue, and participants were asked to respond only to the questions, and meetings were held one-on-one. Compiled interview notes and voice recordings were then summarized and reported with content analysis (Table 1: Distributions and Numbers of Interviewed Executives)

\begin{tabular}{|c|l|c|c|l|c|}
\hline No & Position & Employed Institution & No & Position & Employed Institution \\
\hline 1 & General Manager & 5-star hotel / Istanbul & 5 & General Manager & 5-star hotel / Istanbul \\
\hline 2 & General Manager & 5-star hotel / Istanbul & 6 & Sales Manager & 5-star hotel / Istanbul \\
\hline 3 & General Manager & 5-star hotel / Istanbul & 7 & $\begin{array}{l}\text { Marketing } \\
\text { Manager }\end{array}$ & 5-star hotel / Istanbul \\
\hline 4 & General Manager & 5-star hotel / Istanbul & 8 & $\begin{array}{l}\text { Business } \\
\text { Development } \\
\text { Manager }\end{array}$ & 5-star hotel / Istanbul \\
\hline
\end{tabular}

Table 4.1: Distributions and Numbers of Interviewed Executives

\subsection{Limitations of the Study}

This study has limitations as the research data were gathered only from 5-star chain hotels in Istanbul as a qualitative study, and it was conducted with 8 managers (5 General Manager, 1 Sales Manager, 1 Marketing Manager, and 1 Business Development Manager) with open-ended interview method.

\subsection{Research Questions}

With this study, the following questions were tried to be answered:

- Is there any change in the tourist profiles of the hotel enterprises due to the influence of the Arab Spring? If yes, what kind of changes are observed?

- Is there a need for a difference/change in the service provided by the hotel enterprises due to the influence of the Arab Spring? If so, what kind of differences/exchanges are taking place in services, and how are hotel enterprises trying to respond to these?

- Is there a need for a difference/change in customer expectations with the impact of the Arab Spring? If yes, what are the differences/changes in customer expectations and how does the hotel management try to respond to them?

- What are the differences and characteristic features observed between the tourist profiles of the ones coming from the so-called Arab countries and the others when evaluated in terms of nationality differences?

- Before the Arab Spring, what was the nationality of the tourists mostly preferring Turkey?

- What is the nationality of the tourists who choose hotels mostly in Turkey after the Arab Spring? If there is a change, how do you interpret this change?

- What are the issues that Arab tourists consider important in choosing their hotels?

\subsection{Research Findings}

- Over the last decade, especially in the last 3-4 years, there have been significant changes in the number and profile of the tourists coming to 5-star hotels in Istanbul. The number of tourists from Arab countries has increased due to the influence of the Arab Spring. Because the citizens of Saudi Arabia, Kuwait, Jordan, Bahrain, Iran, Egypt, Iraq, Lebanon, and Qatar, which has the potential of traveling in the Middle East, they started to prefer Turkey more which is posed as safer due to the political insecurity that 
appeared in Egypt. Arabs, especially when overwhelmed with the hotness of the summer season, see Turkey with its 4 seasons as an advantageous destination, and this was supported by its geographical proximity comparing to Europe and the United States (1, $2,3,4,5,6,7,8)$.

- Although in Arabic tradition all issues are dealt with by the males (father/husband/male partner) as the householder, the women have the say in the accommodation preferences. For Arab males, who enjoy special treatment, respect, and sincere dialogues, satisfying the wives and children are essential; they do not want to hear any complaints, therefore, they expect a high level of service. If the family members make a complaint and the hotel does not come up with a solution, they leave the hotel without considering their payment. For the Arabs, word-of-mouth advertising is at the top of the list of reasons for preference. Satisfied families communicate this situation to other families, and if they are not satisfied, this communication appears to be stronger as a mean of revenge-taking $(2,3,4,5,6)$.

- The number of European and Asian tourists coming to 5-star hotels in Istanbul has also declined significantly. This decline is a result of the political conjuncture formed by the fear of Islamic terrorism, security, and public order problems. Especially for European and Asian tourists who attach a great importance to their security, Istanbul has begun not to be the destination of choice or re-arrival other than compulsory travel and cultural tours. It has become a destination for these tourist groups mostly for cultural tours or business and congress meetings. With the increase in the number of Arabs coming for holiday, the hotels of short-term stay for meetings of business and congresses with the "business" concept, were transformed into "leisure" concept that provides longer hosting services. This different market segment and marketing mix presentation, which means a complete strategy change, has led the hotels to new investments and important decisions $(1,2,3,4,5,6,7)$.

- It is very important for Arab tourists to stay in the 5-star hotels, because 5-star hotels in their own countries are very common and ordinary. But it is even more important for them the hotel to be luxurious and glamorous apart from being 5-star. With the influence of this customer group, the concept of 7-star hotel service has emerged globally. That is why most of the 5-star hotels in Istanbul have undergone changes in decoration, design, and service delivery. Hence hotel concepts with visual qualities and quantities desired by the Arabs are being developed $(2,5,6)$.

- As Arab tourists have a high-income level, there is no question of spending money. While liking extreme luxury, the Arabs are careful with the money, and they criticize the service they receive ruthlessly if they do not like, but are also ready to spend a very high amount of money if their expectations are met $(2,3,4)$.

- Contrary to what one might think, in Arab culture, women make all the holiday and shopping decisions. The show of Turkish movies and iTV series in Arab countries (most of which speak of luxurious and glorious life, especially the Ottoman palace sultanate and the luxuries of the Bosporus, etc.) arouses the curiosity of Istanbul and Ottoman in Arab women. Designs and service offerings that meet such expectations are important $(1,2)$.

- The Middle East focused tourism industry exists, but this focus disturbs other tourist groups. In particular, Turkish customers have begun to feel like they are not worth as much as the Arabs. The Europeans who stay in 5-star hotels, with being a more conservative and modern customer group, their expectation is that the promises are fulfilled and the needs they desire are met basically. In that respect, most Arab tourists' loud speaking, messiness, and illegal behavior are disturbing to European tourists. This is one of the socio-cultural differences between the two communities $(1,2,3,5)$. 
- It is observed that Arab guests are not much tidy in the environment where they eat, and often do not like to obey the rules, have delays in meeting their meal times and service hours during the day. Breakfasts are delayed because they wake up late as they sleep too late. For this reason, delays in the operations of the hotel that hosts Arab guests can occur. To prevent this, different alternative business processes and personnel planning should be done $(2,3,4)$.

- It is seen that Arab tourists prefer places close to Istanbul especially during the summer season. The proximity of Yalova, Bursa, Bolu, Sakarya, and İzmit to Istanbul provides alternative sightseeing opportunities. However, they wish to travel to other cities day by day without checking out from their rooms due to their luxury concerns. They choose to use taxis or private vehicles for their one-day travels to these places $(1,5,7,8)$.

- Historical places in Istanbul and leisure-based social life as well as shopping centers are factors that attracts more Arab tourists. Also, increasing number of Arabic-speaking staff in every sector in Turkey turned into an advantage for the Arab tourists. It is noteworthy that both the staff and the written materials are in Arabic widely. For example, today almost every 5-star Istanbul hotel has Arabic speaking room service staff, food and beverage menu, and different service offerings in Arabic (1, 2, 3, 4, 5, 6, 7, 8).

- Istanbul is an opportunity for Arabs who have travel bans to Europe and the United States. Here, modern life and traditional life coexist $(5,8)$.

- Religious items are an important factor for Arab tourists. The Arabs feel comfortable in Istanbul because of the popularity and reputation of the mosques, the absence of barriers to worship, the concept of halal food that is being settled, and common religious values. Among the changes in the presentation of the hotel services are the masjid rooms, the prayer rugs in the room, the prayer beads, and the signs displaying the prayer direction [for Mecca]. In addition, it is also possible to inform the hotel customers about the reliability of the food by oral communication. For this reason, the staff must have an understanding of the content of the menus and should develop the ability to quickly respond to the compliance of the food with the Islamic conditions $(1,2,3,4,5,6,7,8)$.

- As the use of shisha is important for Arab tourists, it is ensured that this is included in the service delivery. It is not acceptable for Arab tourists not to have shisha $(3,7)$.

- As the structure of the potential tourist groups coming to Turkey changed, the marketing strategies as well as the market structure of the 5-star hotels in Istanbul have also changed. More investment has been made in the marketing of 5-star hotels in Istanbul to Arabs for sightseeing and shopping purposes, which are previously used more frequently by European tourists for business trips. For this reason, there has been a difference in the market structure. Development of a marketing mix for a different market segment has been pursued $(1,2,3,4,5)$.

- With the changing market structure, the focus is shifted to the Arab's expectation of glory rather than "business traveler" European tourists' expectation with a minimalist profile. More luxury, rooms with more spaces, Islamic items (room with prayer directions, prayer rugs, holy books, halal food etc.), differences in food varieties, local flavors, investments in enlargements for the room spaces, and an increase in the number of family rooms and number of connected rooms $(4,5,8)$.

- The Human Resources policy of the hotels has changed. The number of Arabic-speaking staff increased with the changing tourist profiles. In addition, the warm-blooded communication desire of the Arab citizens has also changed the structure of guest relations. While Europeans attach importance to a more distant communication, they also changed the structure and content of in-service trainings given to employees, which 
have changed according to Arabs, who like to have a communication style based on close contact and respect $(1,2,3,5)$.

- Luxury is the fundamental expectation for those coming from Arab countries. The thrifty Arabs are extremely generous with respect to luxury and personalized service delivery. This led to the necessity of redesigning and decorating the hotels. Large and luxurious rooms, personalized service offerings became inevitable $(1,2,3,4,5,6,7,8)$.

- It is very important for tourists coming from Arab countries to stay in large groups and families. For that reason, they prefer rooms with all kind of luxuries and comforts that are suitable for family use instead of simple and practical rooms that Europeans prefer $(1,2)$.

- Arab tourists have a high level of consumption and use the room relatively disorganized and noisy, while European tourists are tidier and more economical in terms of room use (in terms of use of bouquet materials, towels, bed linen renewal requests). For this reason, the labor that the floor services spend per room has increased, resulting in the additional staff requirement $(1,5,6,8)$.

- The Arab market, considered as a sustainable market, was developed as an alternative market for a temporary period to European and Asian markets, but it is now turned into the target market. The reason for this is the events that took place in Egypt following the 2010 "Arab Spring" crisis, where the Middle East prefers in tourism. Moreover, change in the perception of Turkey in Europe was also effective (EU - Turkey tensions, etc.). Especially Saudi tourists used to prefer Egypt. They used to find in Egypt the entertainment and social environment that does not exist in their respective countries, and now they started to prefer Turkey as it has similar socio-cultural elements $(1,2,3$, 4, 5, 6, 7, 8).

- Especially during the summer period, Arab citizens tend to leave their countries because of extreme heat. People get out on the streets at night as the weather gets cooler and they walk around for hours. They can also capture this environment in Istanbul. Due to this climatic factor, Egypt and Dubai were indispensable for Arab tourists. Because shopping facilities, entertainment and social life, historical items, and luxury are available in these countries. However, after the Arab Spring, Turkey became Egypt's alternative. Especially during Ramadan, Istanbul's traditional and cultural structure becomes more attractive to Arabs $(2,3,4)$.

- Turkey's closer distance to Arabic countries comparing to Europe is also one of the reasons for preference. Cultural similarity can also be expressed as a factor $(1,2,3)$.

- The availability of halal food is important. They also have a great number of food and beverage options, and that they are suitable for their palate tastes as essential. Especially breakfast is very important. They usually prefer to dine out for the dinners. For this reason, 5-star hotels in Istanbul does not prefer "all inclusive", but "a "la carte". Arabs, who have the understanding of traveling based on sightseeing and catering, seldom prefer eating dinner in the hotel $(6,7,8)$.

- The cost of the Arab customers is higher than the European customers. The facts that they do not obey the rules, expect luxury, being untidy, excessive consumption increases the cost. However, they have been tolerated as their number of expenditure items, expenditure amounts, and tips are high. Especially Northern Europe customers have the lowest costs $(1,2,3,4)$. 


\section{CONCLUSION AND RECOMMENDATIONS}

Significant increases in the arrival of Arab tourists to Turkey has occurred with the Arab spring. Negative political developments such as the terrorist incidents in 2016 and the July 15 (2016) coup attempt caused significant decreases in Istanbul's arrival of tourists from the Western market. Nonetheless, political developments together with the Arab Spring in 2010 led to a significant increase in the arrival of tourists to Turkey from these countries, and this has led to major changes in the tourist profile and services offered in hotels operating in Istanbul. In this study, the dimensions of this change that occurred together with the Arab spring were revealed.

In the direction of the findings from the interviews, it is observed that there are significant changes in the tourist profiles in the 5-star hotel enterprises operating in Istanbul after the Arab Spring which occurred in 2010. This change seems to have caused the hotels to revise themselves on many issues such as human resources, education, food and beverage, cost control, renovation, and refurbishment.

When the arrangements are made in the style that Arab tourists desire in the hotel enterprises operating in Istanbul, it is understood that the investment costs to be made will be met in a short period of time since the increase in the number of guests has been observed.

The decrease in the number of tourists coming from the Western countries like the EU member countries and the USA together with the Arabic tourists becoming more permanent, require making more comprehensive and radical changes. In this context, the in-service training of personnel to be employed should also take this into account. They should attend the exhibitions held in the Middle East more, and Turkey's advantages must be accurately explained. Finally, the economic and socio-cultural effects of Arab tourists on the Istanbul and Turkish tourism sectors can be examined in the future studies. 